\title{
Conceptualizing, Measuring, and Explaining Youths' Relative Absence in Legislatures
}

Aksel Sundström, University of Gothenburg

Daniel Stockemer, University of Ottawa

ABSTRACT This article conceptualizes the relative absence of youth in legislatures, a feature we perceive as a democratic deficit with detrimental consequences. It introduces a new operationalization: the Youth Representation Index. Rather than calculating youths' representation by the percentage of Members of Parliament 35 or 40 years old and younger or legislatures' median age, we argue that scholars should assess youths' parliamentary presence relative to their proportion of the voting-age population. We contribute by assessing the magnitude of youths' underrepresentation across countries, finding that adults 35 years old and younger are generally underrepresented in legislatures by a factor of three and those 40 years old and younger by a factor of two. We illustrate that youths' presence increases under proportional representation electoral systems and with candidate age requirements set at 18 years. Finally, our results illustrate that countries with a younger population display a stronger discrepancy in youth representation.

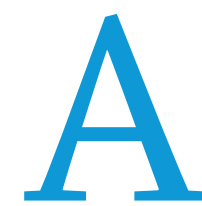

cross societies, youth are characterized by disengagement in electoral politics. They are "less likely to be members of political parties and interest groups and know less about politics" (O'Neill 2007 , iii). In addition, young adults' turnout numbers are significantly lower than those of older generations (Bhatti, Hansen, and Wass 2012; Wattenberg 2015). With regard to political representation, there also is a discrepancy: in many countries, parliaments "include more of the affluent than the less well off, more men than women, more middle-aged than young, and more white-collar professionals than blue-collar workers" (Norris 1997, 6). We see the lack of young adults in legislatures as a democratic deficit that risks further alienating youth from formal politics. Among other factors, youths' low presence in parliaments also is recognized as a problem in debates about the weak political response from current lawmakers to hinder global

Aksel Sundström (D) is associate professor of political science at the University of Gothenburg and a former Visiting Democracy Fellow at the Kennedy School of Government, Harvard University. He can be reached at aksel.sundstrom@pol.gu.se.

Daniel Stockemer (D) is full professor in the School of Political Studies at the University of Ottawa. He can be reached at dstockem@uottawa.ca. warming and introduce gun control (CNN 2019). Yet, comparative research seldom focuses on the relative absence of youth in parliaments.

This article offers a fresh perspective on this aspect of representative democracy and develops a conceptualization of young adults' underrepresentation. We argue that scholars seeking to understand the magnitude of youths' legislative absence should compare their presence in parliament relative to their presence in the population. We introduce a new measurement, the Youth Representation Index (YRI), which gauges the ratio between youth in society and their proportion in parliament. Given the considerable age discrepancies among countries, we deem this measure superior to others, such as the share of legislators 35 or 40 years old and younger and the median age among members of parliament (MPs). For example, the 18- to 35 -year-old population tranche comprises about $20 \%$ of votingage populations in countries with older populations (e.g., Monaco and Japan) and more than 60\% in many low-income countries (e.g., Uganda and Zambia). As such, the YRI provides a more accurate picture of young adults' underrepresentation. Using this index, this article first describes youths' legislative underrepresentation. Second, it highlights which institutional 
and socioeconomic factors explain the underrepresentation of youth across countries.

\section{WHY DOES YOUTH REPRESENTATION MATTER?}

Belonging to the group of young adults is different than other politically marginalized groups. In contrast to gender identity and ethnic-minority status-which seldom change for an individualaging is inevitable and being young is a temporary state in a person's life. Yet, from a group perspective, the presence of youths in legislatures is crucial (Young 1990). Most important, the dominance of older people in legislatures cannot be justified on the basis of their "natural superiority of talent" (Phillips 1995). On the contrary, in the twenty-first century, there is a pool of young, competent candidates qualified to serve in office. In fact, evidence suggests that the problem is not a shortage of candidates but rather their lack of success in elections. For example, the Comparative Candidate Survey (2019)-a joint multinational project averse to increased taxation and the elderly may want higher pensions (Furlong and Cartmel 2012; Jennings and Niemi 2014). Relatedly, youth tend to have more multicultural and egalitarian beliefs (Abramson and Inglehart 2009). For example, young Europeans are more supportive of same-sex marriage than older Europeans (McEvoy 2016). There also is recent evidence that intergenerational cleavages in politics have grown in mature as well as newly established democracies. For instance, Sloam and Henn (2019) suggested that recent elections (e.g., the 2017 UK general election) demonstrated this divide in vote choice.

\section{THE YOUTH REPRESENTATION LITERATURE}

Of the groups that generally are identified as marginalized in political assemblies, including women, ethnic minorities, and LGBTQs, young adults comprise the group that has received the least scholarly attention. To date, the literature on the presence of various age cohorts in elected positions is limited and generally

\section{We see the lack of young adults in legislatures as a democratic deficit that risks further alienating youth from formal politics.}

that collects data on candidates and legislators-illustrates a strong discrepancy between youth in the candidate pool and among MPs. In its sample of 18 elections in 14 countries, candidates ages 18 to 35 comprise nearly $30 \%$ of the candidate pool but only $13 \%$ of all elected representatives. ${ }^{1}$ This illustrates the cynical game that political elites play, often nominating young, aspiring politicians as token candidates on noneligible list positions or for districts they cannot win. Of course, it is possible that young voters might prefer an older candidate when this actor raises policies in tune with their agenda; consider the Bernie Sanders 2019 nomination campaign as a case in point. Nevertheless, nascent research suggests that younger candidates still tend to fare better among young voters (Pomante and Schraufnagel 2015; Saglie, Ødegård, and Aars 2015). supports the claim that youth indeed are underrepresented (e.g., Inter-Parliamentary Union 2014; Joshi 2013; 2015; Kissau, Lutz, and Rosset 2012). For example, Blondel $(1995,257)$ stated that legislators are typically middle-aged to senior. Several case studies of a set of industrialized countries (Norris 1997) and in specific countries (Kissau, Lutz, and Rosset 2012; Murray 2008; Narud and Valen 2000; Prihatini 2019) suggest that the age group between 50 and 60 constitutes the largest proportion of legislators. Two reports on a global sample confirm the relative absence of youths, defined as age 30 or younger (Inter-Parliamentary Union 2014; 2016). In addition to these descriptive works, several analytical pieces seek to explain the underrepresentation of young adults in parliaments (Joshi 2013; 2015; Krook and Nugent 2018; Siaroff 2000; Stockemer and Sundström 2018a; 2018b; 2019).

\section{Of the groups that generally are identified as marginalized in political assemblies, including women, ethnic minorities, and LGBTQs, young adults comprise the group that has received the least scholarly attention.}

The relative absence of young adults in formal politics may feed into ongoing debates on youths' apathy and disengagement (Sloam 2014). In fact, we may have entered a vicious cycle of youth apathy. Because they do not see themselves and their concerns represented, youth might become increasingly disenfranchisedthat is, less likely to participate in conventional politics (Henn and Foard 2012). As a result, parties may cater less and less to the young generation, in terms of policies and political influence (Berry 2014; Van Parijs 1998).

Youth also may have interests and hold views that differ significantly from those of older individuals. To illustrate, some policy areas-for example, rules of military conscription and age limits on the rights of drinking, driving, voting, and running for office-affect young citizens differently. The same is true for public-spending priorities. For example, young adults tend to favor free education, whereas middle-aged people may be more
These articles suggest that three formal institutions should matter for the relative presence of youth in legislatures: lower candidate-age requirements, proportional representation (PR) electoral systems, and age quotas. Allowing younger candidates the right to run for office should produce, on average, a higher proportion of young people in parliament (Krook and Nugent 2018; Stockemer and Sundström 2018b). Under PR, there might be a less significant incumbency advantage because candidates do not need the same recognition or resources as in races in which the "winner takes all." Moreover, with larger district magnitudes, there may be an incentive for parties to adopt diversified lists to appeal to a broad set of constituencies (Joshi 2013; Stockemer and Sundström 2018a). Age quotas for younger citizens could directly affect the presence of young parliamentarians because both legislated rules and voluntary measures within parties should affect the age composition of a legislature (Tremmel et al. 2015). 
Table 1

\section{Operationalization of Independent Variables}

\begin{tabular}{|c|c|c|}
\hline Variable Name & Coding & Source \\
\hline $\begin{array}{l}\text { Electoral-system } \\
\text { type }\end{array}$ & $\begin{array}{l}\text { Two dummy variables: one for proportional representation and one for mixed } \\
\text { electoral systems; plurality is the reference category }\end{array}$ & $\begin{array}{l}\text { International Institute for Democracy and } \\
\text { Electoral Assistance (2017) }\end{array}$ \\
\hline $\begin{array}{l}\text { Candidate-age } \\
\text { requirement }\end{array}$ & $\begin{array}{l}\text { Minimum age to be eligible for the national parliament (the lower house where } \\
\text { applicable) }\end{array}$ & Inter-Parliamentary Union (2017) \\
\hline Age quotas & $\begin{array}{l}\text { Two dummy variables: one for legislative age quotas, one for countries } \\
\text { where at least one party has age quotas }\end{array}$ & Inter-Parliamentary Union (2016) \\
\hline $\begin{array}{l}\text { Economic } \\
\text { development }\end{array}$ & Log GDP per capita & United Nations (2017) \\
\hline Regime type & $\begin{array}{l}\text { Two dummy variables: one for a hybrid regime and one for autocracy; } \\
\text { the reference category is democracy }\end{array}$ & Polity IV (Marshall, Jaggers, and Gurr 2014) \\
\hline $\begin{array}{l}\text { Median age in the } \\
\text { population }\end{array}$ & Median age in the population & Central Intelligence Agency (2019) \\
\hline
\end{tabular}

The existing literature has in common that it measures youth representation by either the median age in parliament or the percentage of legislators younger than age 30, 35, or 40. The first measure, the median age, has limitations because it does not necessarily inform anything about the presence of youth. The second operationalization provides the percentage of youth in parliament. However, without the distribution of the eligible voting-age population, there is no benchmark for comparison with youth in the population. Is a $10 \%$ or $20 \%$ presence of the 18 - to 35 -year-old cohort appropriate? This question can be answered only if we know the proportion of young citizens within the eligible voting-age population in a country. We cannot easily compare youth representation, for example, in Japan and the Dominican Republic; in both countries, young adults comprise less than $5 \%$ of MPs. Yet, the proportion of youth within the eligible voting-age population is 2.5 times higher in the Caribbean country compared to the Asian country (see online appendix 1). As a result, youths' underrepresentation is more pronounced in the Dominican Republic. More generally, there is significant variation in the share of young MPs among countries, ranging from o\% (e.g., Namibia and Palau) to more than $30 \%$ (e.g., Sweden and Serbia). There is similar variation in the percentage of youth in the voting-age population ranging from slightly less than $20 \%$ for countries such as Monaco to more than $60 \%$ for countries such as Uganda.

\section{RESEARCH DESIGN}

The main goal of this article is to create the YRI, which measures the ratio between youth in parliament and eligible voting-age youth in society. We construct this measure for two age groups: those between 18 and 35 years old and those between 18 to 40 years old. The age of 18 was deemed a reasonable choice for the lower bar, given that in most countries in the sample, youth gain citizenship rights at that age. The literature (Joshi 2013; 2015) and international organizations, such as the Inter-Parliamentary Union (2014; 2016), frequently set the upper limit between 35 and 45 years old. To capture this range, the upper limit of our two measures was set at 35 and 40 on the day of the election, respectively. Candidates who take office at age 40 will see their term end at age 45 at the latest.

The data were collected in several steps. First, we consulted national parliaments' websites, contacted parliamentary offices, and researched the website Everypolitician.org (which collects biographies of MPs). The individual data on the age of MPs were aggregated from these websites, and the proportion of MPs ages 18 to 35 and 18 to 40 , respectively, was calculated for all possible legislatures that formed between 2013 and 2017. Second, population data (United Nations 2017) were used to calculate the share of eligible young voters in the population. Again, figures for the same year as the data on legislators were used. For a limited set of small countries, the UN reports only age-distribution figures in quintiles. For these countries, it was necessary to assume that all yearly cohorts within these quintiles were of equivalent size.

Third, the two versions of the YRI were constructed by dividing the percentage of youth in parliament (i.e., MPs ages 18 to 35 ) by the share of youth (i.e., ages 18 to 35 ) within the eligible voting-age population and then multiplying by 100 (the same procedure was adopted for the version of YRI in which age 40 is the upper limit). To illustrate, if the cohort of ages 18 to 35 constituted $15 \%$ of a country's legislature and the same age group comprised $30 \%$ of the population, this measure would be 50 (i.e., young adults' representation in parliament is $50 \%$ relative to their proportion in the population). These two indexes are labeled YRI 35 and YRI 40 , respectively. For comparison purposes, the same indexes for cohorts ages 41 to 60 and 61 and older also were calculated (see online appendices 1 and 2).

We retrieved information about the ratio between youth in parliament and youth in the population for 90 countries (i.e., those with available data on the age of MPs and age-cohort data for the population). These data were used for two types of analyses. First, the legislative underrepresentation of youths across the globe was described. Second, three institutional factors were collected (i.e., the electoral-system type, candidate-age requirements, and existence of legislated and voluntary age quotas) (Joshi 2013; 2015; Stockemer and Sundström 2018a; 2018b), as well as three socioeconomic measures (i.e., economic development, median age in the population, and regime type). Table 1 describes the operationalization of these variables. In the fourth step, the two dependent variables, the YRI 35 and YRI 40, were regressed on these independent variables to explain variations in youth representation. Because the variance was not equally distributed, Huber White Standard Errors were used (White 1980).

\section{RESULTS}

Figures 1 and 2 display strong variation in youths' representation across countries. For example, the YRI 35 ranges from o for 
countries such as Namibia and Palau-indicating that not a single legislator is young-to a small group of only three countries where the parliament has a larger share of youth than the population (i.e., Andorra, Serbia, and Sweden). Yet, the most striking result of YRI 35 is the strong underrepresentation of youth. To illustrate, the average ratio between youths in parliament and in society is 34.55 (the standard deviation is 28.23). In other words, on average, youth are underrepresented by a factor of three-that is, young adults are generally three times more strongly represented in a country's population than in its parliament. To put this figure into perspective with another underrepresented group, women comprise about $24 \%$ of MPs worldwide (Inter-Parliamentary Union 2018). Assuming that the ratio of men and women is about 50/50 in the population, it can be inferred that women's parliamentary representation relative to their presence in society is approximately a factor of one to two.

For the second measure of youth representation, the YRI 40 , there is even greater variation, ranging from o for Palau to almost 150 for San Marino. This second measure also illustrates that the underrepresentation of 40-year-olds and younger at the time of election is less pronounced than the underrepresentation of those age 35 and younger. Nevertheless, this group is still underrepresented by a factor of two.

Regarding possible predictors of variation in youth representation, we find that three variables matter, regardless of whether the YRI 35 or the YRI 40 is regressed on the independent variables (see table 2). First, PR and mixed electoral systems increase the ratio between youth in parliament and in society. Models 1 and
Table 2

\section{Determinants of Youth Representation Across Countries (OLS Regression Models)}

\begin{tabular}{|c|c|c|}
\hline & YRI 35 & YRI 40 \\
\hline $\begin{array}{l}\text { Proportional } \\
\text { representation }\end{array}$ & $\begin{array}{l}13.31^{* * *} \\
(4.39)\end{array}$ & $\begin{array}{l}16.96^{* * *} \\
(4.54)\end{array}$ \\
\hline Mixed electoral system & $\begin{array}{l}24.00^{* * *} \\
(9.00)\end{array}$ & $\begin{array}{l}21.29 * * * \\
(8.29)\end{array}$ \\
\hline Legal candidate age & $\begin{array}{l}-3.20 * * * \\
(0.94)\end{array}$ & $\begin{array}{l}-3.62^{* * *} \\
(0.82)\end{array}$ \\
\hline National youth quotas & $\begin{array}{l}-8.57 \\
(7.98) \\
\end{array}$ & $\begin{array}{l}-6.09 \\
(10.93)\end{array}$ \\
\hline $\begin{array}{l}\text { Parties with youth } \\
\text { quotas }\end{array}$ & $\begin{array}{c}23.40 \\
(22.40) \\
\end{array}$ & $\begin{array}{c}7.00 \\
(10.62) \\
\end{array}$ \\
\hline Log GDP per capita & $\begin{array}{l}-3.23 \\
(4.02)\end{array}$ & $\begin{array}{c}-2.11 \\
(3.72)\end{array}$ \\
\hline Hybrid regime & $\begin{array}{l}-2.76 \\
(5.61) \\
\end{array}$ & $\begin{array}{l}4.61 \\
(6.64) \\
\end{array}$ \\
\hline Autocracy & $\begin{array}{c}3.28 \\
(7.61) \\
\end{array}$ & $\begin{array}{c}2.46 \\
(10.13) \\
\end{array}$ \\
\hline $\begin{array}{l}\text { Median age in the } \\
\text { population }\end{array}$ & $\begin{array}{r}1.84^{* *} \\
(0.712)\end{array}$ & $\begin{array}{l}2.23^{* *} \\
(0.65)\end{array}$ \\
\hline Constant & $\begin{array}{l}40.05 \\
(35.70)\end{array}$ & $\begin{array}{c}33.41 \\
(40.09)\end{array}$ \\
\hline R-Squared & 0.40 & 0.44 \\
\hline$N$ & 90 & 90 \\
\hline
\end{tabular}

\section{Figure 1}

\section{Youth Representation Across the Globe (YRI 35)}

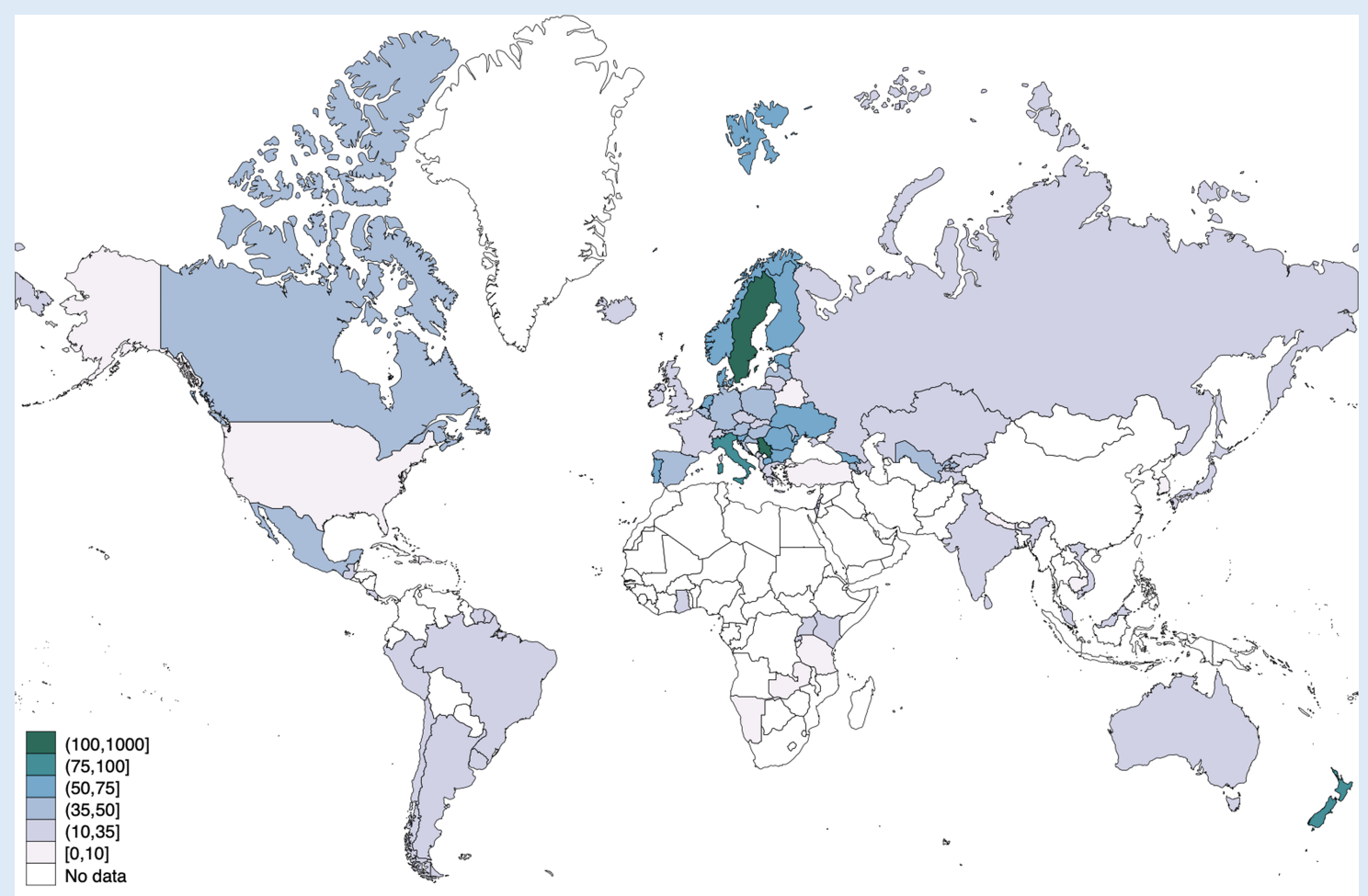

Note: The YRI 35 is a measure in which the percentage of youth in parliament-MPs ages 18 to 35 years-is divided by the proportion of youth (ages 18 to 35 ) within the eligible voting-age population and then multiplying by 100. 


\section{Figure 2}

\section{Youth Representation Across the Globe (YRI 40)}

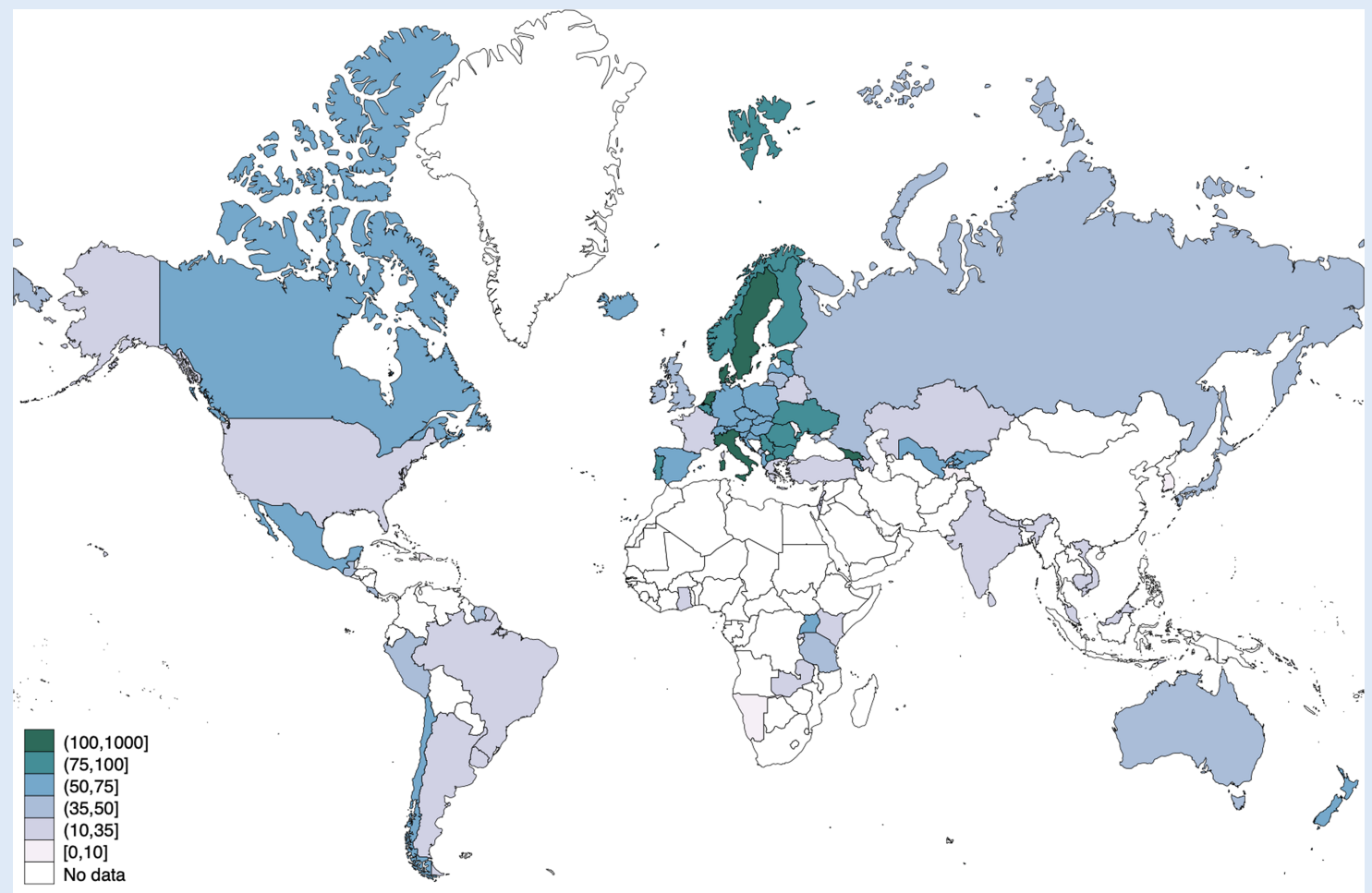

Note: The YRI 40 is a measure in which the percentage of youth in parliament-MPs ages 18 to 40 years-is divided by the proportion of youth (ages 18 to 40 ) within the eligible voting-age population and then multiplying by 100 .

2 predict a $13 \%$ and a $24 \%$ increase on the YRI 35 for PR and mixed electoral systems, respectively. The second variable that increases these indexes is the formal candidate-age requirement: the models predict that either of the two indexes decreases by more than 3 points for every year that the candidate-age requirement increases. In others words, the model predicts that the indexes respected. Although Gabon, Kenya, Kyrgyzstan, Morocco, the Philippines, Rwanda, and Tunisia all have legislative youth quotas-which in some cases even reserves a two-digit share of the seats in parliament for young adults (Inter-Parliamentary Union 2016)-these goals remain distant: the proportion of legislators age 30 years old and younger is, on average, only $2.4 \%$ in

\section{Young adults are still rather an anomaly in parliaments and, if we do not change course, they may become even more indifferent to the representative system. They may realize that the political class neglects their agenda and that representatives bear little resemblance to them.}

decrease by about 25 points for a country where a person must be 25 years old to run for office in the national legislature compared to a country where the official required age is 18 . Third, the gap between youth representation in parliament and in society is larger in countries with a young population; that is, the models predict an approximately two-year increase in the indexes for every year that the median age of a country increases. None of the other variables can explain the variance in these dependent variables. Especially for youth quotas, this was initially surprising. On second thought, however, both legislated and voluntary youth quotas are still selectively applied and, when applied, not fully these countries. In other words, in practice, these countries do not enforce these youth quota laws.

\section{CONCLUSION}

By introducing the YRI, this article contributes to the budding literature on youth representation in three ways. First, we provide a better measurement for youth representation than the percentage of legislators younger than a certain age. Such a measure is static and cannot capture variation in the age distribution of populations. The gap between the two measures often is significant. To illustrate the benefit of these two measures, YRI 35 and 
YRI 40, both Guatemala and Portugal have approximately $15 \%$ of young adults ages 35 and younger in their national legislature. Yet, Portugal as a population is much older than Guatemala, which gives Portugal a higher index score (i.e., 56 versus 26 ).

Second, these indexes illustrate the full dimension of youths' legislative underrepresentation across the globe. Young adults ages 18 to 35 years old are generally underrepresented by a factor of three. From both a normative and a more practical perspective, this is alarming. Normatively, how can a country live up to its (democratic) ideals if it marginalizes a group of the population to such a degree? More practically, these findings shed new light on the potential vicious cycle of youths' political apathy. Young adults are still rather an anomaly in parliaments and, if we do not change course, they may become even more indifferent to the representative system. They may realize that the political class neglects their agenda and that representatives bear little resemblance to them.

For policy, we recommend PR election systems and lowering the official candidate-age requirement to 18 years. However, these reforms will improve youths' presence only moderately. To correct the imbalance between youth in parliament and in the population, it is likely that more drastic measures are necessary-for instance, youth quotas. These quotas should be designed considering youths' presence in their respective society and enforced more rigorously to be effective. For research, we encourage further work on youths' underrepresentation. We calculated the YRI for go national parliaments. Future research should collect more data as they become available for other elected assemblies as well as for cabinets-ideally, both cross sectional and over time. We suspect that renewed research will confirm that the underrepresentation of youth remains visible as well as flagrant.

Third, we strongly encourage future studies to more fully unpack the vicious cycle of youths' underrepresentation. An important question to ask is to what extent young people are actually more likely to vote for young candidates. The literature hints at this direction (Pomante and Schraufnagel 2015; Saglie, Ødegård, and Aars 2015; Ulbig and Waggener 2011), but more research is necessary to establish the degree to which young voters actually demand young politicians.

\section{SUPPLEMENTARY MATERIALS}

To view supplementary material for this article, please visit http:// dx.doi.org/10.1017/S1049096520000906. "

\section{NOTE}

1. These elections were in Germany (2013, 2017), Switzerland (2015), Greece (2015), Sweden (2014), Norway (2013), Hungary (2014), Montenegro (2012, 2016), Albania (2013), Iceland (2013, 2016, 2017), Romania (2016), Finland (2015), Portugal (2015), Chile (2017), and Belgium (2014).

\section{REFERENCES}

Abramson, Paul R., and Ronald F. Inglehart. 2009. Value Change in Global Perspective. Ann Arbor: University of Michigan Press.

Berry, Craig. 2014. "Young People and the Ageing Electorate: Breaking the Unwritten Rule of Representative Democracy." Parliamentary Affairs 67:708-25.

Bhatti, Yosef, Kasper Hansen, and Hanna Wass. 2012. "The Relationship Between Age and Turnout: Curvilinear or a Rollercoaster?" Electoral Studies 31 (3): 588-93.

Blondel, Jean. 1995. Comparative Government: An Introduction. Hertfordshire, England: Harvester Press.
Central Intelligence Agency. 2019. "The World Factbook. Country Comparison: Median Age." Available at www.cia.gov/library/publications/the-world-factbook/ fields/343rank.html. Accessed December 2019.

CNN. 2019. "A 25-Year-Old Politician Got Heckled During a Climate Crisis Speech. Her Deadpan Retort: 'OK, Boomer.” Available at https://

edition.cnn.com/2019/11/o6/asia/new-zealand-ok-boomer-trnd/index.html. Accessed February 2020.

Comparative Candidate Survey. 2019. "Comparative Candidates Survey Module II: 2013-2018 (Dataset-cumulative file). Distributed by the Swiss Centre of Expertise in the Social Sciences, Lausanne, Switzerland.

Furlong, Andy, and Fred Cartmel. 2012. "Social Change and Political Engagement Among Young People: Generation and the 2009/2010 British Election Survey." Parliamentary Affairs 65 (1): 13-28.

Henn, Matt, and Nick Foard. 2012. "Young People, Political Participation, and Trust in Britain." Parliamentary Affairs 65 (1): 47-67.

International Institute for Democracy and Electoral Assistance. 2017. "Table of Electoral Systems Worldwide." Available at www.idea.int/esd/world.cfm.

Inter-Parliamentary Union. 2014. "Youth Participation in National Parliaments." Geneva, Switzerland

Inter-Parliamentary Union. 2016. "Youth Participation in National Parliaments." Geneva, Switzerland.

Inter-Parliamentary Union. 2017. "Parline Database on National Parliaments." Geneva, Switzerland. Available at www.ipu.org/parline-e/parlinesearch.asp.

Inter-Parliamentary Union. 2018. "Women in National Parliaments." Geneva, Switzerland. Available at http://archive.ipu.org/wmn-e/world.htm.

Jennings, M. Kent, and Richard G. Niemi. 2014. Generations and Politics: A Panel Study of Young Adults and Their Parents. Princeton, NJ: Princeton University Press.

Joshi, Devin K. 2013. "The Representation of Younger Age Cohorts in Asian Parliaments: Do Electoral Systems Make a Difference?" Representation 49 (1): 1-16.

Joshi, Devin K. 2015. "The Inclusion of Excluded Majorities in South Asian Parliaments: Women, Youth, and the Working Class." Journal of Asian and African Studies 50 (2): 223-38.

Kissau, Kathrin, Georg Lutz, and Jan Rosset. 2012. "Unequal Representation of Age Groups in Switzerland." Representation 48 (1): 63-81.

Krook, Mona Lena, and Mary K. Nugent. 2018. "Not Too Young to Run? Age Requirements and Young People in Elected Office." Intergenerational Justice Review 4 (2): 60-67.

Marshall, Monty, Keith Jaggers, and Ted Gurr. 2014. Polity IV Project: Dataset Users' Manual. Arlington, VA: Polity IV Project.

McEvoy, Caroline. 2016. "Does the Descriptive Representation of Women Matter? A Comparison of Gendered Differences in Political Attitudes Between Voters and Representatives in the European Parliament." Politics \& Gender 12 (4): 754-80.

Murray, Rainbow. 2008. “The Power of Sex and Incumbency: A Longitudinal Study of Electoral Performance in France." Party Politics 14 (5): 539-54.

Narud, Hanne M., and Henry Valen. 200o. "Does Social Background Matter?” In Beyond Westminster and Congress, ed. Peter Esaiasson and Knut Heidar, 83-106. Columbus: Ohio State University Press.

Norris, Pippa. 1997. Passages to Power: Legislative Recruitment in Advanced Democracies. Cambridge: Cambridge University Press.

O'Neill, Brenda. 2007. Indifferent or Just Different? The Political and Civic Engagement of Young People in Canada. Ottawa: Canadian Policy Research Networks.

Phillips, Anne. 1995. The Politics of Presence. Oxford: Oxford University Press.

Pomante, Michael J., and Scot Schraufnagel. 2015. "Candidate Age and Youth Voter Turnout." American Politics Research 43 (3): 479-503.

Prihatini, Ella S. 2019. "Women Who Win in Indonesia: The Impact of Age, Experience, and List Position." Women's Studies International Forum 72:40-46.

Saglie, Jo, Guro Ødegård, and Jacob Aars. 2015. "Rekruttering av unge folkevalgte." Tidsskrift for Samfunnsforskning 56 (3): 259-88.

Siaroff, Alan. 200o. "Women's Representation in Legislatures and Cabinets in Industrial Democracies." International Political Science Review 21 (2): 197-215.

Sloam, James. 2014. "New Voice, Less Equal: The Civic and Political Engagement of Young People in the United States and Europe." Comparative Political Studies 47 (5): $663-88$.

Sloam, James, and Matt Henn. 2019. Youthquake 2017: The Rise of Young Cosmopolitans in Britain. Cham, Switzerland: Palgrave Macmillan.

Stockemer, Daniel, and Aksel Sundström. 2018a. "Age Representation in Parliaments: Can Institutions Pave the Way for the Young?" European Political Science Review 10 (3): 467-90. 
Stockemer, Daniel, and Aksel Sundström. 2018b. "Youth Representation in the European Parliament: The Limited Effect of Political Party Characteristics." Intergenerational Justice Review 4 (2): 68-78.

Stockemer, Daniel, and Aksel Sundström. 2019. "Young Deputies in the European Parliament: A Starkly Underrepresented Age Group." Acta Politica 54 (1): 124-44

Tremmel, Jörg, Anthony Mason, Petter Haakenstad, and Igor Dimitrijoski. 2015. Youth Quotas and Other Efficient Forms of Youth Participation in Aging Societies. Heidelberg, Germany: Springer Verlag.

Ulbig, Stacy G., and Tamara Waggener. 2011. "Getting Registered and Getting to the Polls: The Impact of Voter Registration Strategy and Information Provision on Turnout of College Students." PS: Political Science \& Politics 44:544-51.
United Nations. 2017. "Per Capita GDP at Current Prices, USD. November 15, 2017." Available at http://data.un.org.

Van Parijs, Phillippe. 1998. "The Disfranchisement of the Elderly and Other Attempts to Secure Intergenerational Justice." Journal of Political Philosophy 4 (2): 101-17.

Wattenberg, Martin P. 2015. Is Voting for Young People? London: Routledge.

White, Huber. 1980. "A Heteroskedasticity-Consistent Covariance Matrix Estimator and a Direct Test for Heteroskedasticity." Econometrica 48 (4): 817-38.

Young, Iris M. 1990. Justice and the Politics of Difference. Princeton, NJ: Princeton University Press. 